\title{
Languages are Wealth: The Sprachbund as Linguistic Capital*
}

\author{
VICTOR A. FRIEDMAN \\ University of Chicago
}

My title is a translation from the Aromanian, Bulgarian, Macedonian, and Meglenoromanian versions of a Balkan proverb followed by a nod to Bourdieu (1991). The folk saying occurs in various forms in all the Balkan languages except Greek. ${ }^{1}$ Thus, for example, the Albanian and Romani equivalents translate 'the more languages you speak, the more people you are worth'. ${ }^{2}$ Turkish and Balkan Judezmo speakers both use the Turkish version: bir lisan, bir insan; iki lisan, iki insan 'one language, one person; two languages, two people.' Folk wisdom valorizing multilingualism can be taken as indicative of the conditions under which a sprachbund can develop, and the exception can be taken as symptomatic of the pressures to eliminate language contact. ${ }^{3}$ I would like elaborate here on these issues by contributing to two important points made by Eric P. Hamp at the Third Annual Meeting of the Berkeley Linguistics Society (Hamp 1977) and by adding two more. First, when we have adequate historical data, we must utilize them in the pursuit of areal explanations for language change: areal linguistics is an historical linguistic discipline. Second, the notion that a sprachbund must have fixed borders like an ideal nation-state, rather than being leaky much as Sapir (1921:38) observed of grammars almost a century ago, is -

\footnotetext{
* The research for this article was supported by grants from the John Simon Guggenheim Foundation, Fulbright-Hays (Department of Education), ACCLES/ACTR Title VIII, and the American Council for Learned Societies with support from the National Endowment for the Humanities and the Scocial Science Research Council. None of these organizations is responsible for the opinions expressed herein.

${ }^{1}$ Brian Joseph (pc) heard the Greek equivalent in conversation with the mayor of a hellenophone village in Albania, but other hellenophone Albanians rejected the expression as imported from the Soviet Union.

2 The Bosnian/Croatian/Montenegrin/Serbian version is like the Albanian and Romani. For the versions in the original languages, see Friedman and Joseph (Forthcoming).

${ }^{3}$ I treat sprachbund as a borrowing from German, like pretzel, rather than as a codeswitch, unless the use is a quotation from another source.
} 


\section{Victor A. Friedman}

to use another of Sapir's metaphors in that passage - tyrannical. ${ }^{4}$ My third point is that the absence of the abovementioned saying from Greek is indicative of the intersection of linguistic ideology and cultural politics that has given Greek a special place in the Balkan sprachbund, that of a nexus of negation of multilingualism. My final point is that, contrary to claims that the Balkan sprachbund ended with the end of the Ottoman Empire, and is therefore an artifact to be consigned to the dustbin of history, the processes that produced it are on-going at the local level, as well as in those polities that have preserved multilingualism as a positive value. Such preservation is fragile, however, and, ironically, some members of the EU are encouraging its demise at the same time as other EU structures are attempting to support it.

Hamp (1977) includes a critique of the conflation of areal and typological linguistics seen in Sherzer (1976) in describing indigenous languages of North America. Among Hamp's (1977:282) points is that what he refers to as "gross inventorizing" of what he characterizes as "a Procrustean bed of parameters" (Hamp 1977:283) cannot capture the historical depth and specificity that give meaning to areal developments. Such numbers games played with a small set of features, characterized by Donohue (2012) as "cherry picking," can produce maps in which languages seem to mimic modern politics, e.g. Haspelmath (1998:273), which shows a French-German-Dutch-North Italian "nucleus" to a presumed "Standard Average European," with the Indo-European Balkan languages at the next level of remove, and with Turkish entirely outside of "Europe." A subsequent representation (Haspelmath 2001:107) has only French and German at its core, with Albanian and Romanian as part of the next closest level, Bulgarian and the former Serbo-Croatian beyond that, and Turkish still totally outside. Van der Auwera (1998:825-827) has dubbed such constructs the "Charlemagne Sprachbund" on the undemonstrated assumption that Charlemagne's short-lived (800-814) empire, or its successor the Holy Roman Empire [of the German Nation; a.k.a. the First Reich] was the nucleus for a linguistically unified Europe whose influence can be detected today in mapping out synchronic feature points. This is, in essence, an extension of Sherzer's (1976) methodology to Europe (cf. also König 1998:v-vi), but rather than being the work of a lone researcher, this project - especially in the version known as EUROTYP - has involved many people, produced many volumes, and has taken place in a political context that is arguably motivated by a vision of what Winston Churchill called "a kind of United States of Europe" in his 1946 speech at the University of Zurich. To be sure, as with Sherzer (1976), the assembled data are welcome. The over-arching quasi-historical conclusion, however, is misleading and the lack of attention to

\footnotetext{
4 The complete quotation is this: "Were a language ever completely 'grammatical' it would be a perfect engine of conceptual expression. Unfortunately, or luckily, no language is tyrannically consistent. All grammars leak.” (Sapir 1921:38).
} 


\section{Languages are Wealth}

historical and dialectological detail of the type called for by Hamp (1977) is problematic.

Van der Auwera's (1998:827) formulation that on the basis of EUROPTYP's investigations "the Balkans do indeed get their Sprachbund status confirmed," while supporting the reference to linguistic capital in my title, nonetheless gives the impression of treating the Balkan languages like the Balkan states vis-à-vis the EU: their status on the international stage is determined in Brussels (the new Aachen) or Strasbourg (in former Lotharingia). ${ }^{5}$ The politics of Western Roman and Eastern Roman (Byzantine) interests, for which the Balkans were always a peripheral but vital pawn, were very much at stake in Charlemagne's time; and the modern-day echoes are striking. But it was precisely the Pax Ottomanica of the late medieval and early modern periods - not Obolensky's (1971) Byzantine Commonwealth - in the regions that were part of the Ottoman Empire from the fourteenth to the beginning of the twentieth centuries, where the linguistic realities of the Balkan sprachbund (as identified by Trubetzkoy) took their modern shape. As can be seen from the textual evidence of such innovations as future constructions and infinitive replacement (see Asenova 2002:214, Joseph 2000), the crucial formative period of the Balkan sprachbund is precisely the Ottoman period, when, as Olivera Jašar-Nasteva said, with one teskere (travel document) you could travel the whole peninsula and, we can add, when much of the Charlemagne's former territory consisted of a variety of warring polities that only consolidated into modern nation-states as the Ottoman Empire broke up. ${ }^{6}$

To be sure, Hamp (1977:280) recognizes areal features that "may be crudely labeled Post-Roman European," but, for example, the spread of the perfect in 'have' into the Balkans has nothing to do with Charlemagne. The construction was a Late Latin innovation, whose origins are already apparent in Cicero and Julius Caesar (Allen 1916: 313), and it made its way into the Balkans with the

\footnotetext{
${ }^{5}$ To a certain extent, this is literally true. In 2005, the European Court of Human Rights in Strasbourg fined the Greek government for violating the human rights of its ethnic Macedonian citizens' in harassing the ethnic Macedonian organization Vinožito 'Rainbow'. In 2006, Vinožito used the money to re-publish the 1925 primer that had been published in Athens for Greece's Macedonian minority, combined with a modern Macedonian primer (Vinožito 2006). However, that same year, on September 29, 2006, at the inauguration of Latvian collector Juris Cibuls' exhibition of primers in Thessalonica, the Deputy Mayor for Culture and Youth of that city ordered the organizers to take the Macedonian primer out of the show case so that it could not be displayed (Juris Cibuls, pc).

${ }^{6}$ Differences in territorial, economic, and social mobility are beyond the scope of this paper, but we can note that during the centuries when Jews were locked into ghettoes in Western Europe, and Roms existed there only as peripatetic outcasts, in Southeastern Europe (i.e., Ottoman European Turkey) Roms were settled in both towns and villages (although some groups were peripatetic), and Jews lived in neighborhoods, not locked streets. The larger varieties of available modes of social (and thus linguistic) interaction implied by such differences should not be underestimated. Moreover, pace Haspelmath (2001), significant grammatical change can take place in the course of only a few centuries, as seen in the data in Asenova (2002) and Joseph (2000); cf. also the changes in English after 1066.
} 
Roman armies, settlers, and Romanized indigenous populations. It became the preterit of choice - independently - in French and Romanian (except in the south; see Pană Dindelegan 2013:33), and continues to displace the aorist in other parts of both Western and Eastern Romance. In Balkan Slavic it was precisely those populations in most intensive contact with the Balkan Romance that became Aromanian that developed independent 'have' perfect paradigms, namely those in what is today the southwest of the Republic of Macedonia and adjacent areas in Greece and Albania (see Gołąb 1976, 1984:134-136 for details). Moreover, it is hardly coincidental that in Bulgarian dialects, it is precisely those that were spoken along the route of the Via Egnatia where similar perfect paradigms developed. As for Greek, as Joseph (2000 and references therein) makes abundantly clear, the use of 'have' as a perfect auxiliary is in fact of very different, albeit also Roman, origin. In Greek, it was the use of 'have' as a future marker - itself a Romance-influenced innovation - that gave rise to an anterior future with the imperfect of 'have' that became a conditional that became a pluperfect that then provided the model for the formation of the perfect using a present of 'have' plus a petrified infinitival form. This stands in stark contrast to the Romance perfect, which began as 'have' plus past passive participle, which participle then ceased to agree, which is exactly the construction that was calqued into Macedonian (and some Thracian Bulgarian). On the other hand, the perfect in the Romani dialect of Parakalamos in Epirus (Matras 2004), is clearly a calque on Greek, as is the innovation of a verb meaning 'have'. Albanian also has a perfect in 'have' plus participle, and the participle itself is historically of the past passive type found in Romance and Slavic. The directionality is difficult to judge. The Albanian perfect is securely in place by the time of our first significant texts in the sixteenth century - a time when it was still not well established in Greek - but the relationship to Latin or Romance influence is difficult to tease out. Such perfects are not found in the Torlak dialects of former Serbo-Croatian, a region where there is presumed to have been early contact with populations whose languages are presumed to have been ancestral to Albanian and modern Balkan Romance, and where there were significant Albanian speaking populations until 1878 (Vermeer 1992:107-108). The Slavic dialects of Kosovo and southern Montenegro - where contact with Romance lasted into the twentieth century and with Albanian is on-going, albeit strained - do not show such developments. ${ }^{7}$ This fact itself may be due to the importance of social factors in language change. Living cheek by jowl does not necessarily produce shared linguistic structures. A certain level of coexistential communication must also involve social acceptance. On the western end of old Roman Empire, Breton is the only Celtic language with

\footnotetext{
${ }^{7}$ According to Rexhep Ismajli (pc), when Pavle Ivić was conducting field work on the old town former Serbo-Croatian dialect of Prizren (southern Kosovo) in the mid-twentieth century, he gathered a group of old women and asked them to count in the old-fashioned way (po-starinski) and they began: ună, dao, trei, patru.... 'one, two three, four (in Aromanian)'.
} 


\section{Languages are Wealth}

a 'have' perfect, and the directionality is clear. Still to describe all these perfects as part of a "Charlemagne Sprachbund" is to do violence to historical facts, although it arguably serves the interest of current political imaginings.

The spread of 'have' perfects exemplifies linguistic epidemiology in Enfield's (2008) sense. And thanks to the depth and detail of our historical records, we can tease out the facts. In some respects, it is heartening to see that humans can program computers to identify, to some extent, insights that humans had without their aid a century or two ago. Thus, for example, as Donohue (2012) demonstrated, WALS (2005) features for the main territorial languages of Europe, when "decoded into binary format, then pushed through computational algorithms (Splitstree) that cluster languages on the basis of "best shared similarity" which he is careful to characterize as explicitly synchronic and not diachronic produces groupings (moving clockwise from the north) for Germanic, Slavic, Balkan, Romance, and Celtic. The details within the groupings are interesting only because we already know the history: Icelandic and Faroese are closer to German than to Scandinavian, while Afrikaans is closer to Scandinavian than to Dutch, and Polish comes between Belarusan and Ukrainian, on the one hand, and Russian, on the other, while Portuguese is much closer to French than it is to Spanish. Moreover, the ability to differentiate areal from genealogical causality that prompted Trubetzkoy to postulate the sprachbund in the first place, is missing. These results demonstrate clearly Hamp's (1977) point: typological, areal, and genealogical linguistics are independent disciplines, the former achronic, the latter two "twin faces of diachronic linguistics" (Hamp 1977:279). Nonetheless, despite its many sins of omission and commission (under representation of socalled non-territorial languages [itself a problematic, bureaucratic notion], absence of crucial dialect facts, misanalyses, misleading generalizations, etc.), WALS (2005) is a blunt instrument that, if welded with care and sensitivity, can at least spur us to consider other approaches, as Donohue (2012) has productively done in his discussion of Australia.

In the context of the putative Charlemagne sprachbund (discussion of which featured on the program of the 46th meeting of the Societas Linguistica Europaea in Split, 18-22 September 2013), it will be instructive to cite here Jakobson's (1931/1971) concept of the Eurasian sprachbund. Jakobson deviated significantly from Trubetzkoy (1930) — who characterized the sprachbund as comprising languages "that display a great similarity with respect to syntax, that show a similarity in the principles of morphological structure, and that offer a large number of common culture words, and often also other similarities in the structure of the sound system" (translation mine) — by positing the notion of phonological sprachbunds and specifically a Eurasian sprachbund, concentrating on consonantal timbre (basically palatalization including some correlations with front/back vowel harmony), prosody (presence vs. absence of pitch accent or tone), and, in a footnote, nominal declension. He set up Eurasia as the center in terms of all these. 


\section{Victor A. Friedman}

For nominal declension, Germano-Romance Europe and South and Southeast Asia were the peripheries; in terms of phonological tone, the Baltic and Pacific areas were the peripheries (with West South Slavic [most of Serbo-Croatian and Slovenian] as a relic island), while for palatalization the core was roughly the boundaries of the Russian Empire, with the inclusion of eastern Bulgaria (which, perhaps not coincidentally, was imagined as Russia's potential zadunajskaja gubernaja 'trans-Danubian province' during the nineteenth and part of the twentieth century). He even went so far as to suggest that palatalization in Great Russian [sic] finds its most complete expression, and it is thus no coincidence that Great Russian is the basis of the Russian literary language, i.e. the language with a panEurasian cultural mission (Jakobson 1931/1967:191). All the foregoing is not to say that linguists positing sprachbunds that match political interests intend to act as tools of foreign policy, but once their works are published they can be adopted and adapted by those with policy goals; and in any case, language ideology appears to be at work.

It is also important to note here that, while Masica (2001:239) warns against confusing "recent political configurations" with "linguistic areas," it is precisely the legacy of political configurations such as the Ottoman Empire that created the conditions for the emergence of the Balkan sprachbund as it was identified by Trubetzkoy. At the same time, humans, like all other animals, are capable of traversing whatever barriers nature or other humans might construct, and thus sprachbunds are indeed not political configurations, with fixed boundaries. It is here that the German Bund 'union' in Sprachbund (in Trubetzkoy's original 1923 formulation, Russian jazykovoj sojuz 'language union' as in Sovetskij Sojuz 'Soviet Union') has misled scholars such as Stolz (2006), who frets that since sprachbunds do not have clearly definable boundaries like language families (or political entities) the concept should be discarded. His "all or nothing" methodology misses Trubetzkoy's original point that the sprachbund is fundamentally different from a linguistic family, and it fails to take into account the basic historical fact that, like the political boundaries and institutions that sometimes help bring sprachbunds into being, the "boundaries" of a sprachbund are not immutable essences but rather artifacts of on-going multilingual processes; in Hamp's (1989:47) words, they are "a spectrum of differential bindings" rather than "compact borders," a point to which he also alluded in Hamp (1977:282). It is also important remember that when Trubetzkoy first proposed the term, it was at a time when the Sprachfamilie 'language family' was widely considered the only legitimate unit of historical linguistics, while resemblances that resulted from the diffusion of contact-induced changes were described in terms such as those used by Schleicher (1850:143), who described Albanian, Balkan Romance, and Balkan Slavic as "agree[ing] only in the fact that they are the most corrupt (die verdorbensten) in their families." Trubetzkoy was explicitly concerned with avoiding the kind of confusion more recently generated by conflations of areal 


\section{Languages are Wealth}

and typological linguistics, although in his time the issues involved areal and genealogical linguistics.

Turning now to language ideology in the Balkans itself, the difference between Greek and the rest is striking. As noted at the beginning of this article, Greek is the only language in the Balkans for which a saying valuing multilingualism is lacking. It is certainly the case that multilingualism itself does not guarantee the formation of a sprachbund. As Ball (2007:7-25) makes clear, in the multilingual Upper Xingu, multilingualism, while necessary for dealing with outsiders, is viewed as polluting, and monolingualism is considered requisite for high status. This endogamous region is quite different from exogamous, parts of Amazonia, where multilingualism is an expected norm, and lexical mixing is viewed negatively, but morphosyntactic convergence is rampant (Aikhenvald and Dixon 2006:237-286). Consider also the vertical multilingualism that Nichols (1997) has identified as characteristic of the Caucasus, which is similar to various Balkan multilingual practices, where specific types of multilingualism will index different types of social status. ${ }^{8}$ Ideologies that consider contact-induced change as symptomatic of pollution and that equate isolation and archaism with purity were at work in the nineteenth century as well, as seen in Schleicher's formulation quoted above. We could even suggest that the Charlemagne sprachbund is an attempt both to redress this nineteenth century failing and to co-opt the new valorization of language contact.

Such is not the case, however, in Greece, however, nor was it the case more than a thousand years ago. Fine (1983:220) has formulated the explanation so clearly that it deserves extended quotation:

By the end of the [eleventh] century, the language of the Bulgarian church became an issue. Byzantium's tolerance of Slavonic was a feature of its foreign policy: the annexation of Bulgaria and Macedonia made the liturgical literary language a domestic matter. Efforts toward the hellenization of the Bulgarian church may well have been the cause for the murder of the Greek bishop of Sardika [modern Sofia -VAF] by a mob in 1082. This policy of hellenization became particularly intense under Archbishop Theophylact of Ohrid (ca. 1090-1109), whose surviving letters are a major source for this period. Theophylact closed Slavic schools, introduced Greek-language services in many places, and encouraged the translation from Slavonic into Greek of many local texts. Theophylact himself translated into Greek the life of Saint Clement.

There also seems to have been a systematic destruction of Slavic manuscripts. Not one Slavic manuscript written prior to the establishment of the Second Bulgarian Empire in the

\footnotetext{
${ }^{8}$ In vertical multilingualism, people in higher villages know the languages of those down the mountain, but those in the lowlands do not bother to learn highland languages. Nonetheless, as Tuite (1999) makes clear, aside from the features of shared glottalized consonants and a few phraseological calques, when examined closely the idea of a Caucasian sprachbund vanishes like a mirage. Hamp (1977), too, noted that the appearance of glottalization in Armenian, on the one hand, and Ossetian, on the other, must have distinct areal diachronic explanations.
} 


\section{Victor A. Friedman}

1180s has survived within Bulgaria. Scholars have long blamed the Ottoman Turkish for the destruction of Bulgarian texts. But though it is certain that many Bulgarian manuscripts were destroyed during and after the Ottoman conquest, still this, as Yugoslav scholar Vladimir Mošin [1963] has shown, is not sufficient explanation. If the Ottomans had been responsible, one would not expect any medieval Bulgarian texts to have survived. However, several hundred manuscripts from the Second Bulgarian Empire have been preserved in Bulgaria. Furthermore, many Greek manuscripts from as far back as the ninth and tenth centuries have been preserved in Ohrid. Thus, Mošin reasonably concludes, a systematic destruction of Slavic manuscripts evidently occurred prior to the thirteenth century, namely during the period when Byzantium ruled Bulgaria. (Those writings from the First Bulgarian Empire which have been discussed in this work have all been preserved abroad, chiefly in Russia.) Not surprisingly, in this atmosphere Bulgarian culture seriously declined. No major Bulgarian writers were active during the Byzantine period. (Fine 1983:220)

During the rise of Balkan nationalisms in the late eighteenth and nineteenth centuries, this same attitude also surfaced. The introduction to the pedagogical lessons of Daniēl (1802) — which contained a quadrilingual manual the goal of which was to eliminate all languages other than Greek that were spoken by Orthodox Christians on what was then still Ottoman territory-is illustrative. Here are the first four lines:

Alvanoi, Vlákhoi, Voúlgari, Allóglōssoi kharéte,

Albanian,Vlahs, Bulgarians, allophones rejoice.2pl:IMP

$K$ ' etoimasthéte óloi sas Rōmaîoi nà genéte.

and prepare:2pl:IMP all you Greek SP become:2pl:PRES

Varvarikè̀n afếnontes glōssan, fōnèn kaì èthē

barbarian forego.PART:PL language:ACC speech:ACC and customs:ACC

Opoû stoùs Apogónous sas nà faínōntai sàn mûthoi.

so.that to.the descendants yours SP appear:3pl:PRES like myths

'Albanians, Bulgars, Vlachs and all who now do speak

An alien tongue, rejoice, prepare to make you Greek.

Change your barbaric tongue, your customs rude forego,

So that as bygone myths your children may them know. ${ }^{9}$ (Greek in Daniēl 1802:vii/English in Wace and Thompson 1913:6)

The same sentiment is expressed somewhat more violently in a sign that was photographed in northern Greece some time in the 1950s. It was authenticated by

${ }^{9}$ In Greek orthography the poem is this:

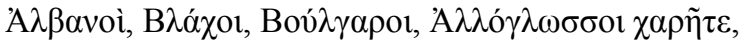

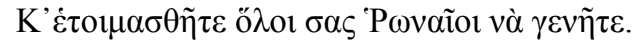

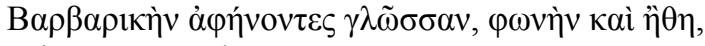

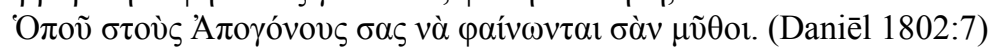




\section{Languages are Wealth}

Kostas Kazazis (University of Chicago), who said that the original colors were blue lettering on white (the Greek national colors). The image is given as figure (1). The translation is based on that supplied by Brian Joseph (Ohio State University). I have left it as literal as possible. It is a concrete example of how language death is sought by a state, but at the same time, it gives indirect evidence that Slavic-speakers in Aegean Macedonia were calling their language 'Macedonian' at that time.

Figure (1) Greek sign forbidding Aromanian and Macedonian

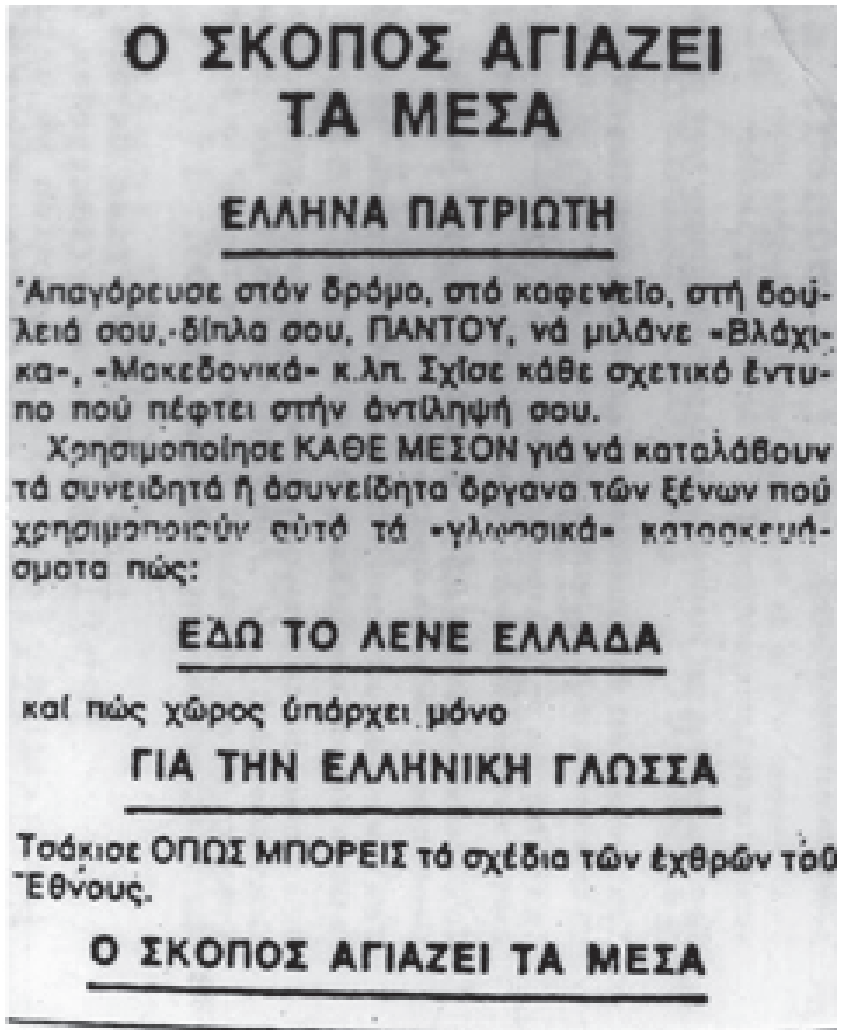

\section{THE END JUSTIFIES \\ THE MEANS \\ O GREEK PATRIOT!}

Forbid in the street, in the cafe, in your job, next to you, EVERYWHERE, that they speak "Vlah", "Macedonian" [Greek makedhoniká —VAF] etc. Tear up every relevant printed document that falls into your perception.

Use EVERY MEANS so that the witting or unwitting instruments of foreigners who use these "language" fabrications might understand that:

\section{HERE IS CALLED GREECE}

and that there is room only

\section{FOR THE GREEK LANGUAGE}

Break up HOWEVER YOU CAN the plans of the enemies of the People. THE END JUSTIFIES THE MEANS 
Although Turkish is permitted in Greek Thrace, the government insists that these Turkish-speakers are "Muslim Greeks" and linguistics even refer to Turkish in Greece as Mousoulmaniká Thrákēs 'Muslimish of Thrace' (Katasanēs 1998).

Greece's denial of the existence of its minorities has even penetrated the world of American men's magazines. The November 2006 issue of Maxim featured a photo spread of international "Miss Maxim"s each a scantily clad and provocatively posed representative of a different country with a putative quotation from the model and a "hometown fact" about the country such as the difference between Holland and Netherlands, the number of bulls killed annually in bullfights in Spain, and the number of tons of radioactive dust released in the 1986 the Chernobyl disaster in Ukraine. The hometown fact for "Miss Maxim Greece" was the following: "According to the Greek government there are no ethnic divisions in Greece" (p. 176).

My most recent experience with Greek linguistic ideology was in September 2012, at the Medžitlija-Niki border crossing between the Republic of Macedonia and the Hellenic Republic, on the Niki side of the border, and subsequently in Florina, Greece. There were four of us in a car on our way from Skopje to the book launch of the first Modern Greek - Modern Macedonian dictionary to be published in Greece. The book launch was taking place in the town of Florina, not far from the border, where there are still many Macedonian speakers. When we got to the Greek side of the border, it turned out that all four of our names were on a hand written piece of paper next to the passport control agent, who informed us we could not enter Greece. He then inspected the car and gave as his justification that fact that the driver had a small, ordinary video camera in his trunk. The European Board of Lesser Used Languages (EBLUL) was having its annual meeting in Florina, and the book launch was supposed to be an event associated with the meeting. The driver called an EBLUL representative in Florina, who called an EU representative in Athens, who called the Greek border, and after an hour of being held and threatened at the border, we were allowed to continue to Florina. When we arrived, we saw a busload of Golden Dawn thugs being brought in to surround the hotel where the EBLUL meeting was taking place. Eventually they were prevented from blocking the entrance, but they stood nearby chanting slogans and making threatening gestures. Such are the dangers of doing minority language research in an EU country.

The Greek ideology - which is well suited to the purposes of the type of classical nationalism that seeks to eliminate language contact and views its effects as "corrupting" - has infected other parts of the Balkans only in recent years. In the Republic of Macedonia today, when one cites the old proverb jazicite se bogatstvo 'languages are wealth' one sometimes receives the reply: no $i$ slabost 'but also a weakness'. The reference here is to relations with Albanian, which in fact are both complex and ideologically cathected. The example of Greece's 


\section{Languages are Wealth}

international success in blocking the Republic of Macedonia's access to various organizations, however, provides an unfortunate justification for similar exclusive nationalism in Greece's neighbors. At the same time, in the Republic of Macedonia, Turkish has re-emerged as the language of urban accommodation. As a consultant of mine put it, it was the mortar that held the bazaar together, and the shopkeeper's buyrum 'please/may I help you' (Turkish) is still the signal of urban coexistence. In the mountains of Gora in southwesternost Kosovo, all the villagers are Muslim, but some speak Albanian and others speak Goran (which is classified as Macedonian, Serbian, Bosnian, or none of the above, depending on the orientation of the speaker or the classifier). ${ }^{10}$ Inter-ethnic tensions are present, demonstrating that common religion does not always determine ethnic feeling in this region. Here the Goran greeting dobar den and the Albanian greeting mirëdita both meaning 'good day' are both marked, and Turkish merhaba is the safest greeting if you're not sure of the ethnicity of your interlocutor.

Finally I should like to say a few words about on-going Balkan linguistic processes. The Kumanovo Arli and Skopje Barutči Romani dubitatives marked by Slavic interrogative $l i$ and Turkish interrogative $m i$, respectively (Friedman 2013), the Albanian use of the 3sg admirative present of 'be' — qenka — as a calque on the Macedonian bilo (an archaic optative usage of the $3 \mathrm{sg}$ neuter old perfect of 'be') meaning 'whether...or...' (Friedman 2012), the tendency of Aromanian doubled prepositions to influence Ohrid Macedonian and then parachute to Skopje (Friedman 2011) are all examples of the fact that the Balkan sprachbund is alive and well in the Republic of Macedonia - the only Balkan nation state to specifically name other Balkan languages in its constitution. At the same time, Balkan multilingualism continues at the local level in all of the Balkan nation states, although trying to study it can be difficult or even dangerous in places like Greece. These facts in turn point to the importance of dialects for understanding language contact. The Balkan sprachbund was identified at a time when Balkan standard languages were at most nascent and nowhere widespread in their effects. Sandfeld's (1930) classic work is based largely on collections of folklore in dialects. While recent Eurocentric (or Eurological) work has focused on standard languages, in fact there is still much dialectological work to be done.

In conclusion, when speaking of language contact in an era of so-called globalization, I would like to make a plea for both the baby and the bathwater, as it were. New contexts of contact require assiduous study, but at the same time, the old ones still merit further attention. Both areal and typological linguistics have much to offer our understanding of how human language works. Nevertheless, as Hamp (1977) pointed out at BLS 3, the two enterprises are fundamentally different. This does not mean that we cannot search for suggestive patterns when

\footnotetext{
10 On purely dialectological grounds, Goran is closest to Macedonian (Vidoeski 2005), and upwardly mobile Gorans have routinely gone to Macedonia, where their dialects are closest to the standard language.
} 
Victor A. Friedman

historical records are lacking, but it does mean that we must pay careful attention to the details of those patterns and that we should not conflate the two for ideological or other purposes.

\section{References}

Aikhenvald, Alexandra Y. and R.M.W. Dixon, eds. 2006. Grammars in Contact: a Cross-Linguistic Typology. Oxford; New York : Oxford University Press.

Allen, Joseph H. 1916. Allen and Greenough's New Latin Grammar. New York: Ginn \& Company.

Asenova, Petja. 2002. Balkansko ezikoznanie [Balkan linguistics]. Veliko Tûrnovo: Faber.

Ball, Christopher G. 2007. Out of the Park: Trajectories of Wauja (Xingu Arawak) Language and Culture. Ph.D. thesis, University of Chicago, Chicago, IL.

Bourdieu, P. 1991. Language and Symbolic Power. Cambridge, MA: Harvard University Press.

Daniēl [Mikhali Adamē Khadzē O] Moskhopolitēs. 1802. Eisagōgikē Didaskalia. [Introductory lessons]. Venice[?]: Nektarion Bishop of Pelagonia.

Donohue, Mark. 2012. Studying contact without studying the languages involved. Paper presented at the 38th Annual Meeting, Berkeley Linguistic Society, Berkeley, CA, 10-12 February.

Enfield, Nick J. 2008. Transmission Biases in Linguistic Epidemiology. Journal of Language Contact - Thema 2:297-306.

Fine, John V. A. 1983. The Early Medieval Balkans. Ann Arbor: University of Michigan Press.

Friedman, Victor, A. 2011. Le multilinguisme en Republique de Macédoine et l'union balkanique aujourd'ui. [Multilingualism in the Republic of Macedonian and the Balkan sprachbund today]. In M. Aymard et al., eds., L'homme et son environnement dans le Sud-Est européen: Actes Xe Congrès de l'Association internationale se Sud-Est européen, 479-481. Paris: Association Pierre Belon.

Friedman, Victor A. 2012. Conjunction Calquing - A Heartland Balkanism. In T. Kahl, M. Metzelin and H. Schaller, eds., Balkanismen heute - Balkanisms Today-Balkanizmy segodnja, 31-37. Vienna: Lit Verlag.

Friedman, Victor A. 2013. The Use of $l i$ as a Marker of Evidential Strategy in Romani. Contrastive Linguistics 38(2-3):253-261.

Friedman, Victor A. and Brian D. Joseph. 2010. The Balkan Languages. Cambridge, UK: Cambridge University Press. 


\section{Languages are Wealth}

Gołąb, Zbigniew. 1976. On the Mechanism of Slavic-Rumanian Linguistic Interference in the Balkans. In Thomas Butler, ed., Bulgaria, Past and Present: Studies in History, Literature, Economics, Music, Sociology, Folklore and Linguistics, 296-309. Columbus, OH: AAASS.

Gołąb, Zbigniew. 1984. The Arumanian dialect of Kruševo in SR Macedonia SFR Yugoslavia. Skopje: MANU.

Hamp, Eric P. 1977. On some questions of areal linguistics. In Kenneth Whistler, Robert D. van Valin, Chris Chiarello, Jeri J. Jaeger, Miriam Petruck, Henry Thompson, Ronya Javkin, and Anthony Woodbury, eds., Proceedings of the 3rd Annual Meeting of the Berkeley Linguistics Society, 279-282. Berkeley, CA: Berkeley Linguistics Society.

Hamp, Eric P. 1989. Yugoslavia crossroads of Sprachbünde. Zeitschrift für Balkanologie 25(1): 44-47.

Haspelmath Martin. 1998. How young is standard average European? Language Sciences 20(3):271-87

Haspelmath, Martin. 2001. The European Linguistic Area: Standard Average European. In Martin Haspelmath, ed., Language Typology and Language Universals, vol. 2, 1492-1551. Berlin: Mouton de Gruyter.

Jakobson, Roman. 1931/1971. Harakteristike evrazijskogo jazykovogo sojuza. [Characteristics of the Eurasian sprachbund]. Selected Writings vol. 1, 143201. The Hague: Mouton. 2nd ed.

Joseph, Brian D. 2000. Textual Authenticity: Evidence from Medieval Greek. In Susan C. Herring, Pieter van Reenen, and Lene Schøsler, eds., Textual Parameters in Older Languages, 309-329. Amsterdam: Benjamins.

Katasanēs, Nikolaos. 1998. Ellēnikè dialektología 5: Oi díglōsses omádes tou ellēnikoú khốrou: Arvanítika - Vlákhika - Ispanoeveraïká - Pomákika Mousoulmaniká Thrákēs - Tsingánika). [Greek dialectology: The languages of the bilingual communities of the Greek people: Arvanitika, Vlah, JudeoSpanish, Pomak, Muslimish of Thrace]. Thessalonica: Ekdotikos Oikos.

König, Ekkehard. 1998. General Preface. In Johan van der Auwera, ed., Adverbial Constructions in the Languages of Europe, v-vii. Berlin: Mouton de Gruyter.

Masica, Colin. 2001. The Definition and Significance of Linguistic Areas. In P. Bhaskararao and K. Subbarao, eds., The Yearbook of South Asian Languages and Linguistics, 205-268. New Delhi: Sage.

Matras, Yaron. 2004. Romacilikanes: The Romani Dialect of Parakalamos. Romani Studies 5 14(1):59-109. 
Victor A. Friedman

Mošin, Vladimir 1963. O periodizacii russko-južnoslavjanskih literaturnuh svjazej $\mathrm{X}-\mathrm{XV}$ vv. [On the periodization of Russian-South Slavic literary connections 10th-15th centuries]. Trudy otdela drevnerusskoj literatury 19:28-106.

Nichols, Johanna. 1997. Modeling Ancient Population Structures and Movements in Linguistics. Annual Review of Anthropology 26:359-284.

Oboblensky, Dimitri. 1971. The Byzantine Commonwealth. New York: Praeger.

Pană Dindelegan, Gabriela. 2013. The Grammar of Romanian. Oxford: Oxford University Press.

Sandfeld, Kristian. 1930. Linguistique balkanique. Paris: Klinksieck.

Sapir, Edward. 1921. Language. New York: Harcourt Brace.

Schleicher, August. 1850. Die Sprachen Europas in systematischer Übersicht. Bonn: König.

Sherzer, Joel. 1976. An Areal-Typological Study of American Indian Languages North of Mexico. Amsterdam: North-Holland.

Stolz, Thomas. 2006. All or Nothing. In Yaron Matras, April McMahon, and Nigel Vincent, eds., Linguistic Areas: Convergence in Historical and Typological Perspective, 32-50. Houndmills, Basingstoke, Hampshire: Palgrave Macmillan.

Trubetzkoy, Nikolai S. 1923. Vavilonskaja bašnja i smešenie jazykov. [The tower of Babel and the confusion of languages]. Evrazijskij vremennik 3:107-24.

Trubetzkoy, Nikolai S. 1930. Proposition 16. In Cornelis de Boer, Jacobus van Ginneken, Anton G. van Hamel, ed., Actes du Premier Congrès International des Linguistes à La Haye, du 10-15 Avril 1928, 17-18. Leiden, The Netherlands: A. W. Sijthoff.

Tuite, Kevin. 1999. The Myth of the Caucasian Sprachbund: The Case of Ergativity. Lingua 108:1-26.

Van der Auwera, Johan. 1998. Conclusions. In Johan van der Auwera, ed., Adverbial Constructions in the Languages of Europe, 813-836. Berlin: Mouton de Gruyter.

Vermeer, Willem. 1992. Serbs and Albanians in Yugoslavia. Yearbook of European Studies 5:101-124.

Vidoeski, Božidar. 2005. Dialects of Macedonian. Bloomington, IN: Slavica.

Vinožito 2006. Bukvar/Anagnōstiko ['Primer' Macedonian/Greek]. Thessalonica: Batavia.

Wace, A.J.B. \& M.S. Thompson. 1913. The Nomads of the Balkans. New York: Dutton. 


\title{
Languages are Wealth
}

WALS. 2005. The World Atlas of Linguistic Structures, ed. by Martin Haspelmath, Matthew S. Dryer, David Gil, and Bernard Comrie. Oxford: Oxford University Press.

\author{
Victor A. Friedman \\ Department of Linguistics \& \\ Department of Slavic Languages and Literatures \\ University of Chicago \\ vfriedm@uchicago.edu
}

